\title{
Representing ozone extremes in European megacities: the importance of resolution in a global chemistry climate model
}

\author{
Z. S. Stock ${ }^{1}$, M. R. Russo ${ }^{1,2}$, and J. A. Pyle ${ }^{1,2}$ \\ ${ }^{1}$ Centre for Atmospheric Science, Department of Chemistry, University of Cambridge, CB2 1EW, UK \\ ${ }^{2}$ National Centre for Atmospheric Science, Department of Chemistry, University of Cambridge, CB2 1EW, UK
}

Correspondence to: Z. S. Stock (zss21@cam.ac.uk)

Received: 23 August 2013 - Published in Atmos. Chem. Phys. Discuss.: 23 October 2013

Revised: 14 February 2014 - Accepted: 6 March 2014 - Published: 17 April 2014

\begin{abstract}
The continuing growth of the world's urban population has led to an increasing number of cities with more than 10 million inhabitants. The higher emissions of pollutants, coupled to higher population density, makes predictions of air quality in these megacities of particular importance from both a science and a policy perspective. Global climate models are typically run at coarse resolution to enable both the efficient running of long time integrations, and the ability to run multiple future climate scenarios. However, when considering surface ozone concentrations at the local scale, coarse resolution can lead to inaccuracies arising from the highly nonlinear ozone chemistry and the sensitivity of ozone to the distribution of its precursors on smaller scales. In this study, we use UM-UKCA, a global atmospheric chemistry model, coupled to the UK Met Office Unified Model, to investigate the impact of model resolution on tropospheric ozone, ranging from global to local scales. We focus on the model's ability to represent the probability of high ozone concentrations in the summer and low ozone concentrations, associated with polluted megacity environments, in the winter, and how this varies with horizontal resolution.

We perform time-slice integrations with two model configurations at typical climate resolution $(\mathrm{CR}, \sim 150 \mathrm{~km})$ and at a higher resolution $(\mathrm{HR}, \sim 40 \mathrm{~km})$. The CR configuration leads to overestimation of ozone concentrations on both regional and local scales, while it gives broadly similar results to the HR configuration on the global scale. The HR configuration is found to produce a more realistic diurnal cycle of ozone concentrations and to give a better representation of the probability density function of ozone values in urban areas such as the megacities of London and Paris. We find the observed differences in model behaviour between CR and
\end{abstract}

HR configurations to be largely caused by chemical differences during the winter and meteorological differences during the summer.

\section{Introduction}

Tropospheric ozone is both an important air pollutant and a greenhouse gas, and therefore has the ability to affect both air quality and climate (Jacob and Winner, 2009). Globally, background ozone levels have generally been increasing over the past few decades, although recent trends suggest that the ozone increase is slowing in some European and American cities (Vingarzan, 2004; Parrish et al., 2012). High surface concentrations of ozone are a particular concern for human population exposure because of the adverse effect of ozone on human health (Monks et al., 2009). Damage to ecosystems including crop damage can also occur at high ozone concentrations.

As the world's urban population grows, poor air quality continues to be a particular concern for the world's megacities (Molina and Molina, 2004; Gurjar et al., 2008). Megacities, as major emitters of ozone precursor gases, can also have impacts on ozone air quality across much larger hemispherical scales (Lawrence et al., 2007; Butler and Lawrence, 2009), although it is thought that the impact of megacities on the global ozone budget remains relatively small (Butler et al., 2012; Stock et al., 2013). Ozone within megacities can be produced locally by precursor emissions, or transported over long distances from other sources (Wild and Akimoto, 2001; West et al., 2009; Fiore et al., 2009; Parrish et al., 2011). Ozone produced locally in polluted 
environments involves a complex set of reactions, whereby emitted CO and volatile organic compounds (VOCs) are oxidised to form ozone in the presence of $\mathrm{NO}_{\mathrm{x}}$ (Chameides and Walker, 1973). At high concentrations of $\mathrm{NO}_{\mathrm{x}}$, ozone is depleted through reaction with $\mathrm{NO}$, leading to low ozone concentrations in very $\mathrm{NO}_{\mathrm{x}}$ rich environments, for example in the centre of megacities. The ozone chemistry is highly nonlinear (Sillman et al., 1990; Liu et al., 1987; Lin et al., 1988), with the amount of ozone produced being dependent on the chemical regime, as determined by the ratio of $\mathrm{NO}_{\mathrm{x}}$ : VOCs (Sillman, 1995, 1999). The continental transport of ozone and its precursors was a focus in the recent Hemispherical Transport of Air Pollutants (HTAP) report (HTAP, 2010), while the effect of local megacity emissions on ozone was specifically addressed in the recent MEGAPOLI project (MEGAPOLI = Megacities: emissions, urban, regional and Global Atmospheric POLlution and climate effects, and Integrated tools for assessment and mitigation; http://megapoli.info; Baklanov et al., 2010).

Capturing the nonlinearity of this ozone chemistry accurately using the global chemistry climate models currently used for climate studies is difficult due to the coarse grid resolution at which the models are typically run. Previous studies have shown that model resolution is key to accurately modelling ozone production (Esler et al., 2004; Tie et al., 2010) and to the ability to reproduce observed ozone concentrations (Tang, 2002; Wild and Prather, 2006; Yoshitomi et al., 2011). At coarse grid resolutions, larger grid boxes mean greater averaging of emissions, of chemistry and of meteorological processes (Jang et al., 1995). This can lead to inaccurate representation of the ozone chemistry in areas of sharp emission gradients, such as the transition from urban to rural regions (Sillman et al., 1990; Wild and Prather, 2006).

The averaging of emissions in large grid cells presents a problem in representing emissions from megacities and smaller urban conurbations, as the coarse resolution of a climate model means the grid cells are often larger than the cities themselves. The effect of emission resolution on ozone has been the focus of a number of studies (for example, Tang, 2002; Hodnebrog et al., 2011). Hodnebrog et al. (2011) show that increasing emission resolution is important for local scale spatial changes in ozone concentrations, but less important on larger scales. However, they did not include the impact of model resolution changes on meteorology, which could have additional effects. The homogeneity of emissions across a large grid cell can also affect the chemistry and rate of reactions between species. Previous studies have considered this through parametrisations of the sub-grid chemistry to take into account varying species concentrations across the grid cell (Thuburn and Tan, 1997; Pyle and Zavody, 1990). Parametrisations of sub-grid processes have also been implemented in the case of ship or aviation plumes (e.g. Meijer et al., 1997; Cariolle et al., 2009; Franke et al., 2008; Charlton-Perez et al., 2009). The individual characteristics of megacities, both in terms of emissions and chemistry, make parametrising megacities difficult, especially as the emissions interact with chemistry depending on the local composition and background influences (Hodnebrog et al., 2011).

In this paper we use the global chemistry-climate model UM-UKCA (http://www.ukca.ac.uk) to show that high resolution is beneficial for capturing the magnitude and diurnal cycle of ozone in highly urbanised areas, such as megacities, and to investigate how model resolution alters the temporal and spatial distribution of ozone across larger scales. A full description of the model and experiment setup can be found in Sect. 2. A focus is placed on representing ozone over the regional European domain and in particular on the megacities of London and Paris, chosen as special interest cities in the European MEGAPOLI project (Baklanov et al., 2010). The impact of resolution on surface ozone is considered on a global scale (Sect. 3.1), regional scale (Sect. 3.2), and on the local scale (Sect. 4). The purpose of this is to highlight the ability of the model to reproduce ozone concentrations at each scale, and to highlight areas where the resolution makes large differences to modelled ozone values. We then analyse differences in the emission resolution, chemistry and meteorology to explain the main causes of the modelled differences (Sect. 5). We offer insight into the benefits and limitations of running a global chemistry climate model at high resolution, and discuss the implications for future ozone air quality modelling across a range of scales.

\section{Methodology}

Model integrations are performed using the UK Chemistry and Aerosols (UKCA) model (Telford et al., 2010; Archibald et al., 2011; O'Connor et al., 2014), coupled to an atmosphere-only version of the UK Met Office Unified Model (UM version 7.3) (Hewitt et al., 2011). The model was run in two different configurations: the Climate Resolution (CR) integrations were performed at a horizontal resolution of $1.875^{\circ}$ in longitude $\times 1.25^{\circ}$ in latitude $(\sim 150 \mathrm{~km})$; the High Resolution (HR) integrations were performed at a horizontal resolution of $0.56^{\circ} \times 0.375^{\circ}(\sim 40 \mathrm{~km})$. Note that changing the model grid box requires changes to model timestep and also to some of the parameters in the model parametrisation schemes which are resolution dependent. For example, both model resolutions use the convection and boundary layer schemes based respectively on Gregory and Rowntree (1990) and Lock et al. (2000), but different options and parameters are used to allow for differences in grid box size and length of the timestep (more details of the two model configurations and parametrisation schemes can be found in Walters et al., 2011). The impact of these further differences is difficult to disentangle from the simple effect of the horizontal grid resolution as they are an integral part of the model configuration. We therefore consider the effect of both grid resolution and all other differences as broadly 
due to model resolution. In this study, both model configurations have 63 hybrid sigma-height levels in the vertical, with a model top at $\sim 41 \mathrm{~km}$. To produce suitable initial conditions for present-day integrations, a nudging technique (Telford et al., 2008) was used to perform a $3 \mathrm{yr}$ spin-up run (constrained to a perpetual 2005) using the less computationally expensive CR model. Free-running CR and HR monthly integrations were performed for July and November 2005 using dynamical and chemical initial conditions from the nudged run. July and November were chosen as being representative of summer and winter conditions and although a longer run period would be desirable, when limited by computational restrictions a month is a long enough period to address the distribution of chemical species with relatively short lifetimes (particularly at the surface where emissions and fast chemical reactions dominate ozone production and loss). A summary of the runs performed can be found in Table 1. Figures S1-S4 of the Supplement to this article show the modelled meteorological conditions for the months in question and a comparison to ERA Interim reanalysis (Simmons et al., 2007).

A tropospheric chemistry scheme, described in Telford et al. (2010) and O'Connor et al. (2014), is used to represent chemical cycles of $\mathrm{O}_{\mathrm{x}}, \mathrm{HO}_{\mathrm{x}}$ and $\mathrm{NO}_{\mathrm{x}}$ as well as the oxidation of $\mathrm{CO}$ and other non-methane hydrocarbons as previously described in Zeng and Pyle (2003). The oxidation of isoprene is included by implementation of the condensed Mainz Isoprene Mechanism (MIM) as described in Pöschl et al. (2000). Photolysis rates for photochemical reactions are calculated using the fast-JX photolysis scheme (Neu et al., 2007; Telford et al., 2013) in the CR configuration, while the HR configuration uses a 2-D photolysis scheme (Law et al., 1998). Preliminary studies show that the impact of the photolysis scheme on surface ozone is small. Upper boundary conditions for ozone and $\mathrm{NO}_{\mathrm{y}}$ are fixed to climatological values above $70 \mathrm{hPa}$ : ozone is constrained using the Rosenlof climatology (Dall'Amico et al., 2010) and $\mathrm{NO}_{\mathrm{y}}$ is overwritten from zonal mean values from the Cambridge 2-D model (Law and Pyle, 1993a, b). Concentrations of long-lived species such as $\mathrm{CO}_{2}, \mathrm{CH}_{4}, \mathrm{~N}_{2} \mathrm{O}$ and CFCs are fixed to constant values representative of the year 2005. Surface emissions for the chemical species are generated from the emission data set by Lamarque et al. (2010), as developed for the IPCC fifth assessment report, and updated to 2005 using the RCP-8.5 scenario (Riahi et al., 2011). Isoprene emissions are taken from the POET database (Granier et al., 2005; Olivier et al., 2003) and biomass burning emissions are for the year 2005 taken from the Global Fire Emissions Database (GFED) version 3 (van der Werf et al., 2010). A full description of other biogenic emissions can be found in O'Connor et al. (2014). The gridded global emissions data are initially available at a spatial resolution of $0.5^{\circ} \times 0.5^{\circ}$ and are subsequently interpolated to the $\mathrm{CR}$ and HR model grid for use in model integrations. In all runs, sea surface temperatures and sea ice cover for the year 2005 are prescribed from the AMIP data set (http://www-pcmdi.llnl.gov/projects/amip).

\section{Results}

\subsection{Global ozone evaluation}

We first analyse the impact of resolution on the global scale by comparing monthly mean tropospheric ozone column densities for the CR and HR runs. Figure 1 shows that the tropospheric global ozone distribution is broadly similar for CR and HR. Peak ozone columns are observed for both model configurations in tropical regions, decreasing at mid-latitudes and over the Antarctic continent. The calculated change in total global ozone burden between CR and HR runs is small and shows that HR tends to produce slightly higher values compared to $\mathrm{CR}(\sim 4 \%$ higher in November and $\sim 6 \%$ higher in July). Further calculation of the ozone burden for smaller latitude-height regions revealed that most of the difference between the HR and CR ozone burdens is found in the tropics between $\sim 750 \mathrm{hPa}$ and $\sim 250 \mathrm{hPa}$. Previous studies looking at the impact of model resolution on tropical convection (Russo et al., 2011) have shown that higher resolution models have a better representation of convection, with more frequent deep convection occurring over islands and peninsulas, as opposed to neighbouring sea areas, and generally higher convective cloud top heights. Both of these features would contribute to different lightning $\mathrm{NO}_{\mathrm{x}}$ emissions in the tropics in HR compared to CR; this is because the amount of $\mathrm{NO}_{\mathrm{x}}$ emitted is proportional to the convective cloud top height, and additionally, for a cloud top height of $\sim 8-10 \mathrm{~km}$, our modelled lightning $\mathrm{NO}_{\mathrm{x}}$ emissions are $\sim 40$ 100 times larger when lightning strikes over land compared to sea (Price and Rind, 1992). Even small differences in the distribution and amount of $\mathrm{NO}_{\mathrm{x}}$ in the tropical upper troposphere can have a large impact on ozone production due to the high sensitivity of ozone to $\mathrm{NO}_{\mathrm{x}}$ in these clean environments (Stevenson et al., 2006).

Overall we can infer that, in this study, the impact of increasing model resolution on global ozone burden is small $(\sim 5 \%)$, with differences being largest in the tropical midtroposphere likely due to differences in the model representation of convection. We can therefore conclude that an increase in model resolution might not be necessary to investigate long-term changes in global ozone distributions and tropospheric ozone burden.

\subsection{European ozone evaluation}

To consider regional differences, we focus on ozone over the European continent. Modelled surface ozone concentrations are evaluated using ozone data from the European Monitoring Evaluation Programme (EMEP) network (EMEP, 2007). Monthly mean data for 2005 is gathered from over 100 different rural and urban background stations during the time 
Table 1. A summary of the UM-UKCA runs performed.

\begin{tabular}{llrrl}
\hline Name & Description & $\begin{array}{r}\text { Grid } \\
\text { resolution }\end{array}$ & $\begin{array}{r}\text { Emissions } \\
\text { resolution }\end{array}$ & $\begin{array}{l}\text { Period } \\
\text { run for }\end{array}$ \\
\hline CR spin up & Climate resolution run (nudged) & $1.875^{\circ} \times 1.25^{\circ}$ & $1.875^{\circ} \times 1.25^{\circ}$ & 3 yr (perpetual 2005) \\
CR & Climate resolution run (free running) & $1.875^{\circ} \times 1.25^{\circ}$ & $1.875^{\circ} \times 1.25^{\circ}$ & Jul, Nov 2005 \\
HR & High resolution run (free running) & $0.56^{\circ} \times 0.375^{\circ}$ & $0.56^{\circ} \times 0.375^{\circ}$ & Jul, Nov 2005 \\
\hline
\end{tabular}
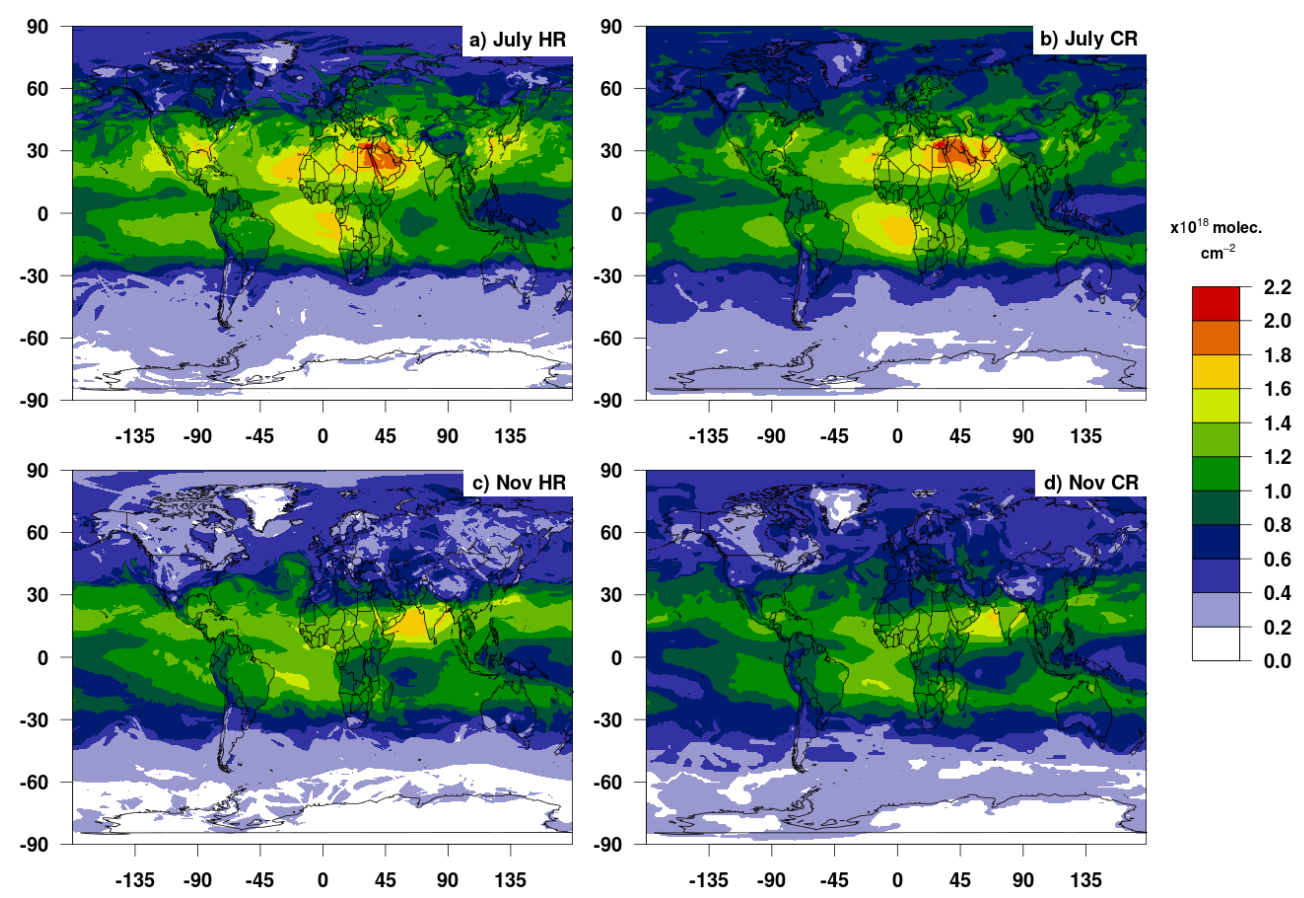

Fig. 1. Global distribution of monthly mean tropospheric ozone column from runs at high resolution HR and climate resolution CR for July and November 2005.

periods chosen. As well as comparing model results at all EMEP sites, we also investigate further differences between the two model configurations by selecting subsets of the EMEP sites with similar characteristics, grouping sites according to location or by the magnitude of ozone observed. Fourteen stations were chosen as "background" ozone sites, sites that lie away from the influence of direct emission sources, in particular on the western edge of the European domain (experiencing clean air from the Atlantic) or south of Europe in the high ozone concentrations of the Mediterranean. Ozone at these sites is indicative of background ozone concentrations and we therefore expect both the HR and CR runs to capture ozone at these sites well. A second subset of EMEP stations was selected based on a low ozone criterion. Polluted urban areas such as megacities often have lower ozone than their surroundings due to titration of ozone by high concentrations of NO. It is therefore useful to consider how well the model runs capture ozone at these polluted sites. As titration effects are more pronounced in the winter, the sampling was based on monthly mean ozone values in November being lower than a $15 \mathrm{ppb}$ threshold; the same stations were used in July for consistency. Sites that fall into both categories are considered only in the low ozone subset to avoid duplication. The location of background and low ozone sites within the EMEP network is shown in panel a of Fig. 2.

A first measure of the model's ability to reproduce observed ozone values over Europe is the percentage of sites for which monthly mean modelled ozone is within a factor of 2 of the observations. A comparison of measured-modelled ozone concentrations for July shows that both HR and CR configurations have over $95 \%$ of ozone values within a factor of 2 of the observations (panel b in Fig. 2). However, both model configurations share a tendency to overestimate the observed ozone concentrations. Sites that have low observed ozone, in particular the sites at Aliartos, Greece, and Montelibretti, Italy, are greatly overestimated in the CR model run. Overall, the CR model seems to perform similarly to the HR model in July, when photochemical production plays a large role and ozone values are generally highest. 

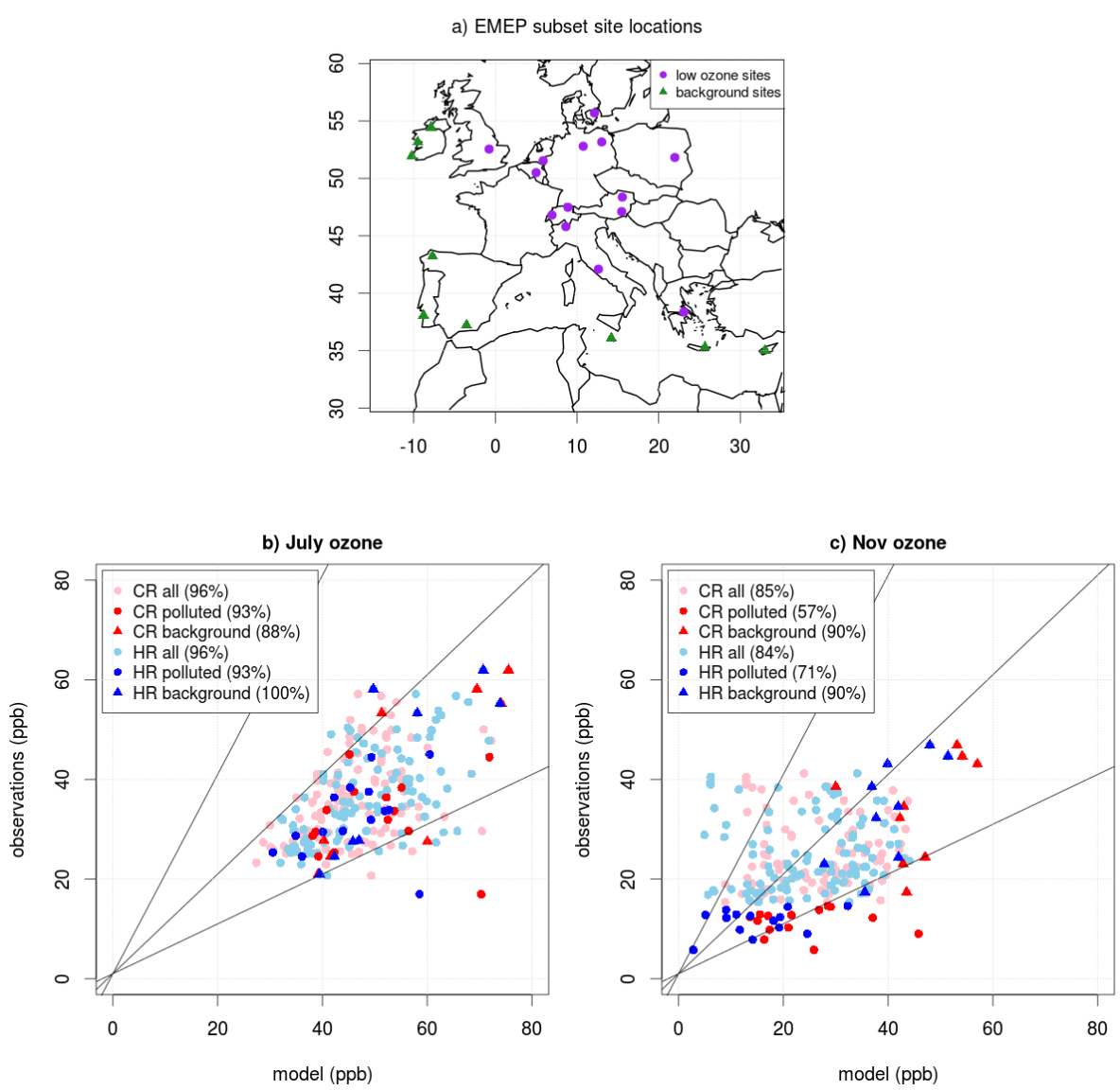

Fig. 2. (a) The locations of two subsets of the EMEP stations, showing background sites (green), and sites with low ozone (purple). A full definition of both subset criteria can be found in the text. (b and $\mathbf{c}$ ) Monthly average comparison of modelled to observed ozone concentrations for sites across the EMEP network. Results are shown for climate resolution (red) and high resolution (blue). Polluted sites are highlighted in bold circles, and background sites in bold triangles. The percentage of model concentrations within a factor of 2 of the observations is included in the legend.

In contrast, for November only $84-85 \%$ of the modelled ozone concentrations fall within a factor of 2 of EMEP observations (panel c in Fig. 2). Both model integrations seem to perform reasonably well at background sites, but tend to overestimate the low ozone values at more polluted sites, a problem which is again more pronounced for the CR run. In a comparison of summertime surface ozone trends (1991-2005) across Europe using the GEOS-Chem model, Koumoutsaris and Bey (2012) also find that ozone is overestimated at the low end of the distribution, which they attribute to the coarse model resolution. Overall, in both months the HR integration represents the ozone values at background stations slightly better than CR, with $90-100 \%$ of the concentrations within a factor of 2 of observations. In November, the HR integration better captures the lower ozone values associated with more polluted regions, while CR largely overestimates ozone at these sites.

A simple quantitative error analysis similar to that of Martins (2012) and widely used in model validation techniques is used to further discriminate between HR and CR results. Monthly mean modelled and observed ozone concentrations from the EMEP network are used to calculate the model correlation coefficient $(r)$, standard deviation $(S)$, root mean square error (RMSE) and mean bias error (MBE), shown in Table 2 for both July and November. The MBE is an indication of the model tendency to over- or under-predict observed values. The RMSE is calculated as in Borrego et al. (2008). A low value for RMSE and MBE shows a good match between model and observations, with 0 the perfect score. The standard deviation of the model $(S)$ is calculated as the square root of the model variance. The standard deviation of the observations $\left(S_{\text {obs }}\right)$ is calculated in the same manner using the observational data, and ideally the standard deviation of the model and the standard deviation of the observations are approximately equal. $S_{\mathrm{obs}}$ is found to be $9.31 \mathrm{ppb}$ and $8.64 \mathrm{ppb}$ for July and November respectively (see Table 2 for model comparison). The statistics are in agreement with the results in Fig. 2 with generally similar values for HR and CR in July, 
Table 2. UKCA statistical results comparing ozone from the climate (CR) and high resolution (HR) runs to observations from the EMEP network (EMEP, 2007). The subsets of EMEP sites are as defined in the text and shown in Fig. 2. Note that $S_{\text {obs }}$ is found to be $9.31 \mathrm{ppb}$ and $8.64 \mathrm{ppb}$ for July and November respectively.

\begin{tabular}{lllrr}
\hline Month & & EMEP sites & CR & HR \\
\hline July & Correlation $(r)$ & all & 0.40 & 0.60 \\
& & polluted & 0.09 & 0.34 \\
& & background & 0.84 & 0.82 \\
& MBE $(\%)$ & all & 29.7 & 32.8 \\
& RMSE $(\mathrm{ppb})$ & all & 14.9 & 14.7 \\
& S (ppb) & all & 9.70 & 9.96 \\
& Slope & all & 1.24 & 1.29 \\
\hline \multirow{2}{*}{ Nov } & Correlation $(r)$ & all & 0.28 & 0.32 \\
& & polluted & -0.03 & 0.33 \\
& & background & 0.37 & 0.64 \\
& MBE $(\%)$ & all & 14.4 & 3.2 \\
& RMSE $(\mathrm{ppb})$ & all & 12.3 & 11.7 \\
& (ppb) & all & 10.93 & 10.97 \\
& Slope & all & 1.06 & 0.96 \\
\hline
\end{tabular}

except for polluted sites, for which HR performs slightly better. Both resolutions show a large positive bias in the July results; this is linked to higher ozone concentrations in summer months, caused by enhanced photochemistry compared to winter months. However, in November the statistical analysis shows that HR performs better than CR for background as well as polluted sites, with the HR model bias being particularly low.

Finally, to address the impact of resolution on the modelled ozone distribution over Europe, we compare monthly mean surface ozone maps from HR and CR runs for July and November, as shown in Fig. 3. Ozone concentrations from EMEP stations are shown as coloured circles. Both model configurations generally capture the spatial pattern of ozone well, with lower concentrations across central Europe and higher concentrations in southern Europe and the Mediterranean. In July ozone values are generally higher than November (note the different colour scale) and both model configurations share a tendency to overestimate ozone, particularly in northern and central Europe.

In November, the HR configuration is better able to reproduce the very low ozone values associated with pollution hotspots, such as the Po Valley in Italy, the Rhine-Ruhr Valley in Germany and the London-Birmingham corridor in the UK. In winter, precursor emissions dominate ozone concentrations through ozone titration effects: the higher grid resolution retains the large precursor emissions and their horizontal gradients, whereas with a coarse resolution grid, ozone precursor emissions are spread over a larger area. In both months, the lower ozone values associated with large cities are better resolved in the HR run, largely due to the higher emission resolution, an effect which is discussed fur- ther in Sect. 5. Coastal boundaries, and the associated landsea ozone gradients, are better resolved in the HR run. Some large islands in the Mediterranean and large areas of Italy and Greece are not correctly represented as land in the CR run, resulting in overestimation of ozone concentrations across these locations, as ozone deposition over the sea is typically small compared to that over land (Coleman et al., 2010). The low ozone in the Po Valley and high ozone in mountain ranges, such as the Pyrenees and Alps, are also better resolved in the model HR configuration due to the higher resolution orography.

Overall, we find that increasing model resolution leads to improvements in the representation of regional ozone, shown by small increases in $r$, decreases in RMSE and bias and closer agreement to the spatial distribution and magnitude of observations. In particular, the HR run is able to better capture ozone gradients related to the representation of surface characteristics and the very low ozone concentrations associated with emission hotspots in the winter month of November.

\section{Local ozone and its temporal variation}

We now address the question of how the model resolution affects ozone concentrations on the local scale, and we concentrate specifically on the two European megacities of London and Paris. The health impacts of high ozone concentrations are potentially greatest in megacities where population densities are large. It is therefore important to investigate how well the model can capture the complex ozone photochemistry by addressing how well the ozone temporal evolution and ozone extremes are represented in such polluted environments.

The ability of the model to represent ozone in megacities is evaluated against data from two air quality observation networks, the London Air Quality Network (LAQN) (www.londonair.org.uk) and the Airparif network (http:// www.airparif.asso.fr). In London, we use hourly data averaged across 12 sites from the LAQN network. Stations were selected based on the availability of data, with the intention of gaining a wide distribution across central London which includes roadside as well as urban background sites. In Paris, four central sites are used from the Airparif network. Fewer sites are used for Paris, a city which is smaller and more compact than London.

In order to assess the model's ability to capture ozone chemistry in polluted megacity environments, we use hourly data from HR and CR runs to construct monthly averaged diurnal cycles of surface ozone (Fig. 4) and probability density functions (PDFs) of ozone concentrations (Fig. 5) for London and Paris in July and November. The modelled surface ozone in both megacities shows a marked diurnal cycle similar to observations (see Fig. 4). Both model configurations can reproduce the shift in the daily ozone peak going from mid-afternoon in July to early afternoon in November. 

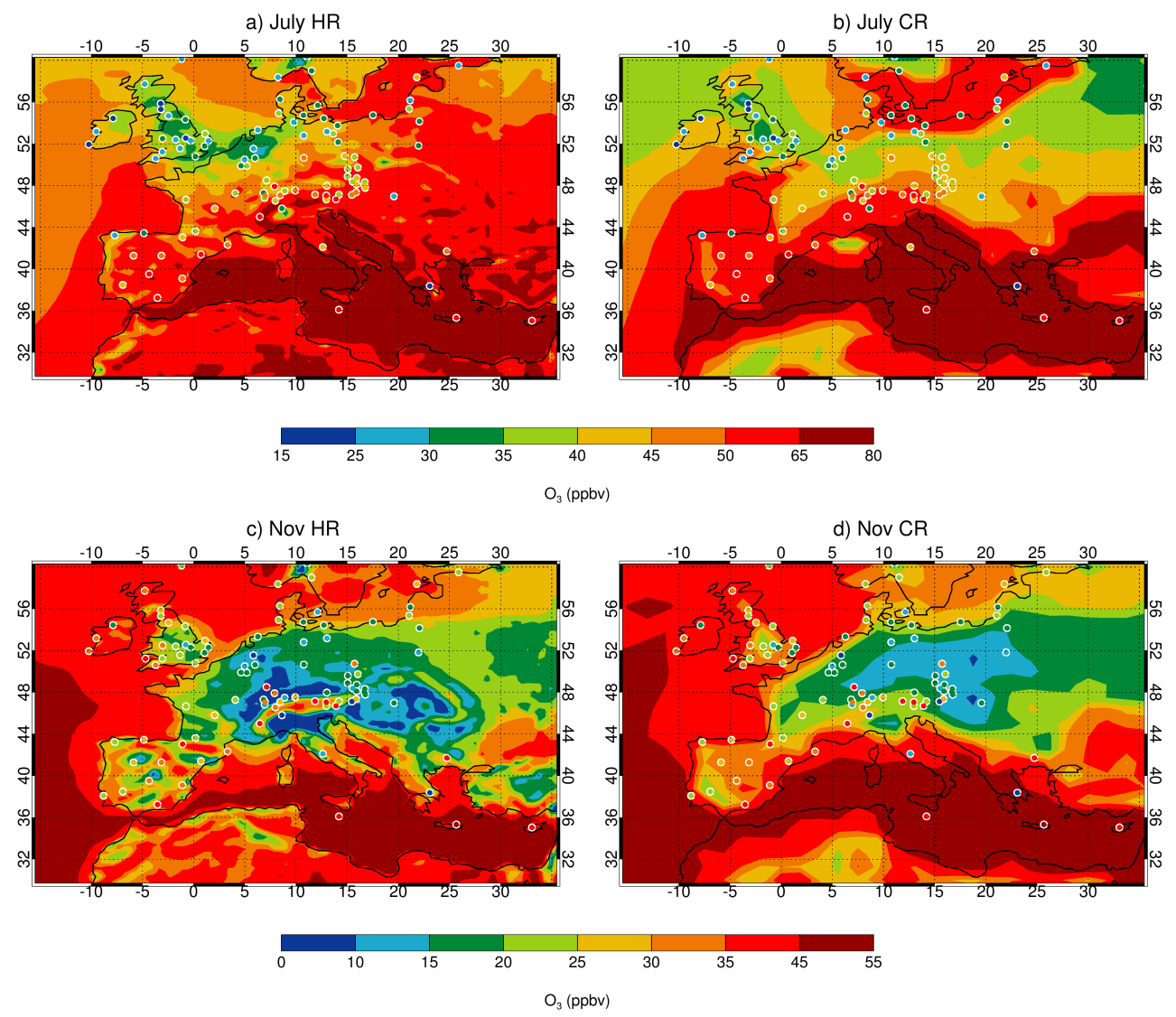

Fig. 3. Monthly mean surface ozone concentrations across Europe for CR and HR. Circles denote observations from the EMEP network.

Note that the model configurations use a relatively simple representation of precursor emissions, which includes a seasonal cycle but has no weekly or diurnal cycle to match the higher emissions from rush hour traffic. However, the temporal evolution of ozone is captured reasonably well by both model configurations, since the photochemistry of the emitted $\mathrm{NO}_{\mathrm{x}}$ leads to a strong diurnal variation in the $\mathrm{NO}$ to $\mathrm{NO}_{2}$ ratio.

Figure 4 shows that the magnitude of ozone concentrations is generally better captured in the HR configuration whereas the CR has a tendency to overestimate ozone values. However, the HR configuration tends to underestimate ozone at night-time in Paris (panels b and d of Fig. 4). This is possibly due to the simple treatment of $\mathrm{NO}_{\mathrm{x}}$ emissions, which results in $\mathrm{NO}$ concentrations being too high at night and the model overestimating the amount of ozone lost through titration.

Similarly, Fig. 5 shows that the HR configuration can better reproduce the shape of the ozone distribution compared to CR, which has a flatter PDF and tends to locate the largest probabilities at ozone concentrations much higher than observed. Additionally, the high probability of very low ozone values observed in both megacities for the winter month of November is better captured in the HR runs (panels $\mathrm{c}$ and $\mathrm{d}$ in Fig. 5). This is linked to high NO concentrations leading to ozone titration, a process more effective at HR due to the higher emission resolution. For the summer month of July, when ozone concentrations are highest, the CR configuration shows a greater tendency to overestimate the observed probability of high ozone values in London, although both model configurations underestimate the same probability in Paris (panels a and b of Fig. 5).

The PDF analysis supports the conclusion that the HR configuration is better able to capture the surface ozone at the local scale. Increasing the model horizontal resolution leads to an improvement in the model's ability to represent both the average magnitude of the ozone diurnal cycle and the high probability of low ozone extremes observed in both megacities in November. However, the probability of high ozone events in July is not particularly well captured by either model configuration. The simple representation of ozone precursor emissions, or the inability of the model to realistically capture extreme meteorological conditions, such as persistent high pressure systems leading to high ozone events, might be possible reasons for this discrepancy. 

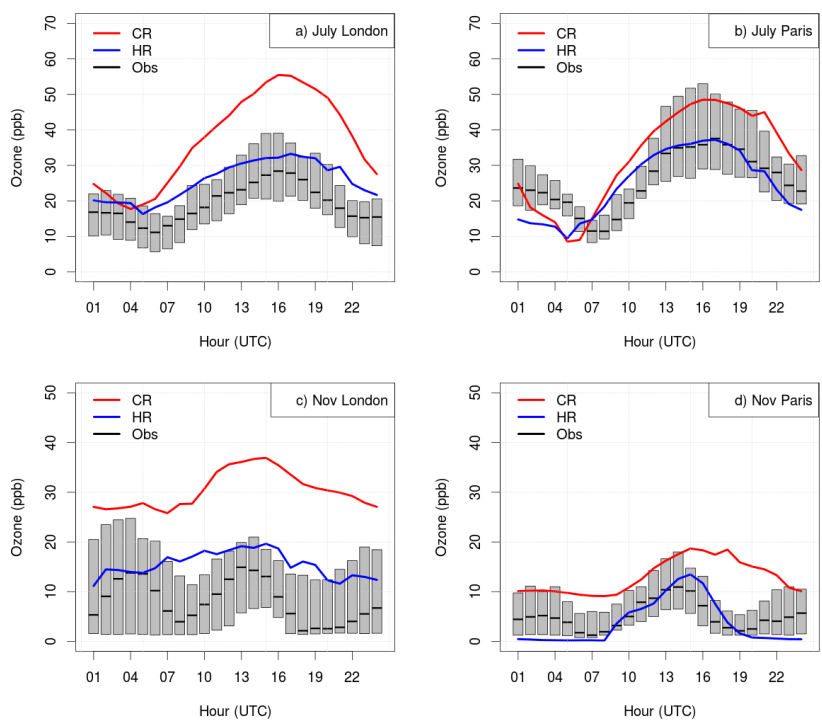

Fig. 4. July and November diurnal cycles of surface ozone for the megacities of London and Paris. The diurnal cycle is calculated as a monthly average with the median values plotted for the climate resolution (CR) in red and the high resolution (HR) in blue. The median from observations is in black, with 25 th and 75 th percentiles highlighted by grey shaded bars.

\section{Discussion}

Ozone chemical production and loss is crucial in determining ozone concentrations. Near the surface, these processes are largely influenced by local ozone precursor emissions and transport (such as boundary layer venting and horizontal transport by surface winds). The different rates of ozone deposition on land, sea and vegetation also play an important role in determining the distribution of surface ozone. In a complex model, where chemistry and meteorology are both influenced by model resolution, all these processes are strongly interlinked. In this section we discuss possible factors contributing to the differences highlighted in the previous section and assess the sensitivity of the modelled ozone to different chemical and meteorological factors across different spatial scales. Model resolution was shown to have a small impact on ozone at the global scale and the differences observed have been discussed in Sect. 3.1. We therefore concentrate on the factors which are more likely to affect ozone differences between HR and CR at the regional and local scale.

We first consider a series of chemical diagnostics to address the differences in ozone concentrations between the two model configurations. Due to the nonlinearity of ozone chemistry, the ratio of $\mathrm{NO}_{\mathrm{x}}$ to VOCs in the environment is a crucial factor for determining ozone chemical production and loss (Jenkin and Clemitshaw, 2000; Sillman, 1995, 1999). As the ratio of $\mathrm{NO}_{\mathrm{x}}$ to VOCs at the surface is sensitive to emissions and initial conditions, we expect resolu-
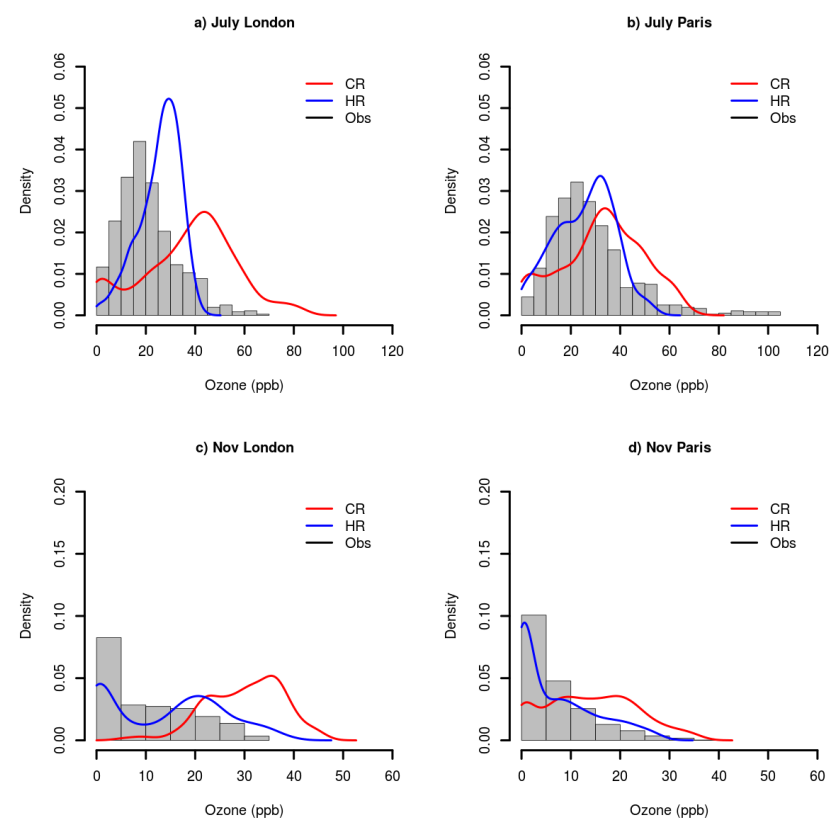

Fig. 5. July and November probability density functions (PDFs) of surface ozone for the megacities of London and Paris. The PDFs are calculated from hourly data points, with the climate resolution (CR) plotted in red and the high resolution (HR) plotted in blue. The PDF of observations is plotted as grey bars. Note the differing scales between July and November.

tion to influence the chemical regime. Rural sites and regions downwind of ozone precursor emissions are generally $\mathrm{NO}_{\mathrm{x}}-$ limited (with ozone production increasing with $\mathrm{NO}_{\mathrm{x}}$ concentrations) whereas more polluted areas are typically VOClimited (with ozone production increasing with VOC concentrations). In very polluted areas, such as urban areas and megacities, the very high $\mathrm{NO}_{\mathrm{x}}$ concentrations can lead to efficient ozone removal through direct reaction of ozone with NO (ozone titration). To diagnose the chemical regime, and how it varies with season and model resolution, we use the ratio of hydrogen peroxide to nitric acid formation (Sillman, 1995). Going from high to low ratios in Fig. 6 denotes a transition from $\mathrm{NO}_{\mathrm{x}}$-limited to VOC-limited regimes. Figure 6 shows that the modelled chemical environment is generally $\mathrm{NO}_{\mathrm{x}}$-limited over the oceans, away from direct $\mathrm{NO}_{\mathrm{x}}$ emissions, and VOC-limited over polluted regions. Differences between the model configurations are larger in November: in this month the CR run is missing the very low values in the more polluted areas which are normally associated with ozone titration and therefore very low ozone concentrations (see also Fig. 3). The formation ratios are typically higher in July for both model configurations, with chemical regimes generally being more $\mathrm{NO}_{\mathrm{x}}$-limited due to the increase in photochemically generated $\mathrm{HO}_{\mathrm{x}}$. Where the environment is clearly $\mathrm{VOC}$ or $\mathrm{NO}_{\mathrm{x}}$-limited, resolution makes only a small difference to the diagnosed chemical regime. However, sharp gradients and changes in chemical regime, 
particularly in winter months at the boundary of a highly polluted urban region to rural surroundings, are better captured in the HR model.

Another useful chemical diagnostic is the ozone production efficiency (OPE), defined as the net number of molecules of ozone produced per molecules of $\mathrm{NO}_{\mathrm{x}}$ lost (Liu et al., 1987; Lin et al., 1988). We calculate OPE as the ratio of ozone production to $\mathrm{NO}_{\mathrm{x}}$ lost for a limiting case, in which the only loss of $\mathrm{NO}_{\mathrm{x}}$ is the oxidation of $\mathrm{NO}_{2}$ by $\mathrm{OH}$. On a regional scale over Europe, our analysis shows that areas where the CR run overestimates surface ozone concentrations compared to the HR run, also have a greater OPE in the model. Once again, differences between the two model configurations seem to be relatively small in July and significantly more pronounced in November. We calculate average OPE over a smaller European domain, defined as -10 $10^{\circ} \mathrm{E}$ and $45-65^{\circ} \mathrm{N}$, which includes the megacities of London and Paris. Values of monthly average OPE range between 2 and $5 \mathrm{~mol} \mathrm{~mol}^{-1}$ over this region. The average OPE in the model for this domain is $\sim 1 \%$ higher in the CR run in July and $\sim 21 \%$ higher in November, compared to the HR run. These differences demonstrate the impact that model resolution has on the chemistry at this scale. The influence is more pronounced in very polluted environments in the winter months, when the concentration of ozone precursor gases dominates ozone production.

The differences in chemical regime and OPE between the two model configurations are ultimately linked to the concentrations of $\mathrm{NO}_{\mathrm{x}}$ and other ozone precursor gases. Coarser resolution is known to spread out $\mathrm{NO}_{\mathrm{x}}$ and VOC emissions by averaging across a larger grid. Previous studies have shown that lower $\mathrm{NO}_{\mathrm{x}}$ emissions, as a result of coarse resolution grid-averaging, increase the ozone production efficiency (Sillman et al., 1990; Jacob et al., 1993; Liang and Jacobson, 2000; Esler et al., 2004). To address the extent to which the differences discussed above can be attributed to the higher emission resolution in the HR configuration, we performed an extra sensitivity run for the month of November. In this sensitivity experiment the HR model is run with the same resolution emissions as the CR model, while everything else in the model configuration is unchanged. Differences between these two HR runs highlight the contribution to ozone differences due to the emission resolution. We focus on November since the chemical regime and OPE analyses suggest that, in July, resolution plays a small role on the model chemistry. When comparing monthly mean ozone concentrations averaged across all EMEP sites, we find that the difference in emission resolution accounts for $\sim 30 \%$ of the difference between the HR and CR runs. However, some regional surface ozone features shown in Fig. 3, such as the very low ozone over the Po Valley region, are still well represented despite using coarser resolution emissions, confirming that surface characteristics and meteorology also play a large role at the regional scale. When going down to the local scale, for the megacities of London and Paris, emission resolution becomes the dominant factor. The average ozone concentration for London in November is $\sim 50 \%$ higher when using coarse resolution emissions and this accounts for $\sim 55 \%$ of the difference between the HR and CR runs. For Paris, the impact of emission resolution is even greater: the average ozone concentration in November when using coarse resolution emissions is $\sim 4$ times larger compared to the standard HR run and is furthermore $\sim 15 \%$ larger than the CR run.

We therefore conclude that, in winter months, emission resolution accounts for about one third of the observed difference between CR and HR at the European scale, but it has an even greater impact on the local scale for highly polluted urban environments, for which dilution of $\mathrm{NO}_{\mathrm{x}}$ emissions significantly reduces ozone titration by NO. This supports the conclusions of Hodnebrog et al. (2011) that the resolution of emissions is important for local scale, air quality studies, but less relevant on regional and global scales.

Finally, we discuss the impact of model resolution on the transport of both ozone and ozone precursor gases at the regional and local scale. Boundary layer height (BLH) is a key measure of vertical mixing near the surface and can also impact horizontal transport on the regional scale. The impact of BLH on ozone concentrations depends on the chemical environment experienced by a particular region. Generally, when ozone production downwind of precursor emissions dominates, and particularly in summer, when increased photochemistry leads to efficient ozone production, a higher boundary layer spreads the ozone vertically and therefore results in lower ozone concentrations at the surface. However, in polluted areas at times when ozone titration dominates, a lower boundary layer leads to build up of $\mathrm{NO}$ emitted at the surface and therefore results in lower surface ozone concentrations.

Figure 7 shows a comparison of BLH for the CR and HR runs. The impact of resolution on BLH is generally higher in July, with the CR configuration underestimating BLH over much of the European domain, compared to the HR run. In both November and July the HR run has a higher boundary layer over central Europe, which corresponds to the lower ozone concentrations found over these regions. Features such as the Po Valley, and its associated lower boundary layer, are better resolved at HR due to a better representation of the orography. Additionally, the BLH field is more homogeneous in CR compared to HR, particularly in November, and this lack of sharp horizontal gradients in BLH would promote horizontal transport across a large area of central Europe. Focusing on the megacities of London and Paris, the HR and CR configurations both have similar BLHs in November, and therefore differences in surface ozone concentrations cannot be attributed to differences in vertical mixing. However, in the summer month of July, the BLH has a much stronger diurnal profile for both model resolutions and the CR configuration has a consistently lower BLH for both London and Paris compared to HR. This suggests that the CR tendency to overestimate surface ozone concentrations in July (see Fig. 4) 

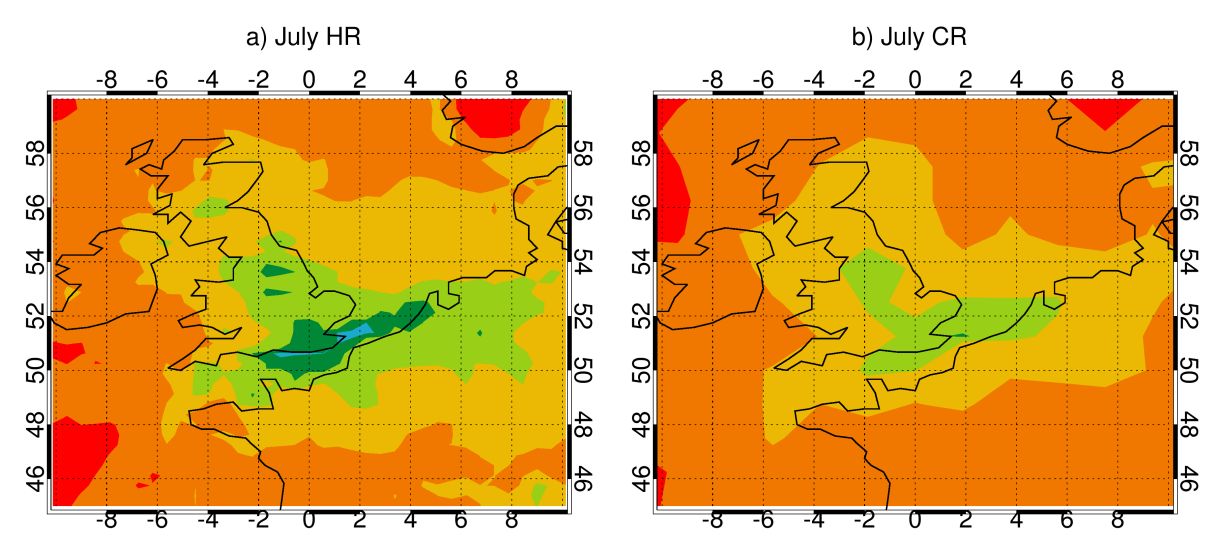

c) Nov HR
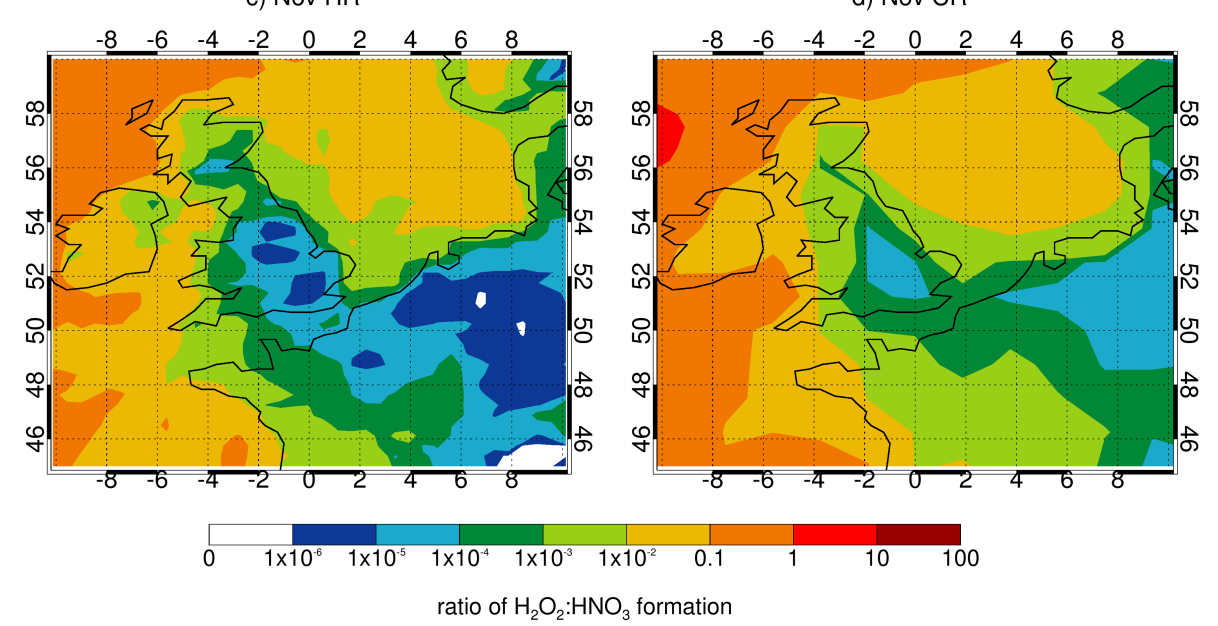

Fig. 6. Monthly mean surface chemical regime as indicated by the ratio of $\mathrm{H}_{2} \mathrm{O}_{2}: \mathrm{HNO}_{3}$ formation. Blue colours indicate a more VOClimited environment and red colours indicate a more $\mathrm{NO}_{\mathrm{x}}$-limited environment.

can be partly explained by a less efficient vertical mixing due to lower BLHs.

To summarise, our analysis indicates that in the summer months, when photochemical production and ozone concentrations are highest, vertical mixing plays a key role in determining surface ozone concentrations and changes in BLH due to model resolution are partly responsible for the observed differences between HR and CR at the regional and local scale. In the winter months, emission resolution can drive changes in chemical regimes and OPE, and can account for a large part of the observed differences between HR and $\mathrm{CR}$ at the regional and local scale.

\section{Conclusions}

We have run the global chemistry-climate model UM-UKCA at typical climate resolution $(\mathrm{CR}, \sim 150 \mathrm{~km})$ and higher resolution (HR, $\sim 40 \mathrm{~km}$ ) to investigate the impact of horizontal resolution on tropospheric ozone at a variety of scales. Model integrations were performed for present day conditions for the months of July and November, representing typical summer and winter conditions.

At the global scale, there is only a small difference $(\sim 5 \%)$ between the CR and HR results. Ozone concentrations are higher in the HR results in the tropical mid-troposphere suggesting that the influence of model resolution on the representation of convective cloud properties and the associated emission of $\mathrm{NO}_{\mathrm{x}}$ from lightning is the main contributing factor to the observed differences.

At the local scale, we compared modelled surface ozone for the megacities of London and Paris to measurements from local air quality networks (LAQN and Airparif respectively). The surface ozone diurnal cycles and PDFs are better captured at HR. In particular, the very low ozone values associated with polluted areas at night are better captured by the HR configuration. Our analysis shows that, in the winter month of November, there are large differences in the OPE between HR and CR, and the improvements shown in the HR results are mainly driven by the higher emission resolution, which accounts for over $50 \%$ of the difference in London ozone concentrations. Conversely, we suggest that the 

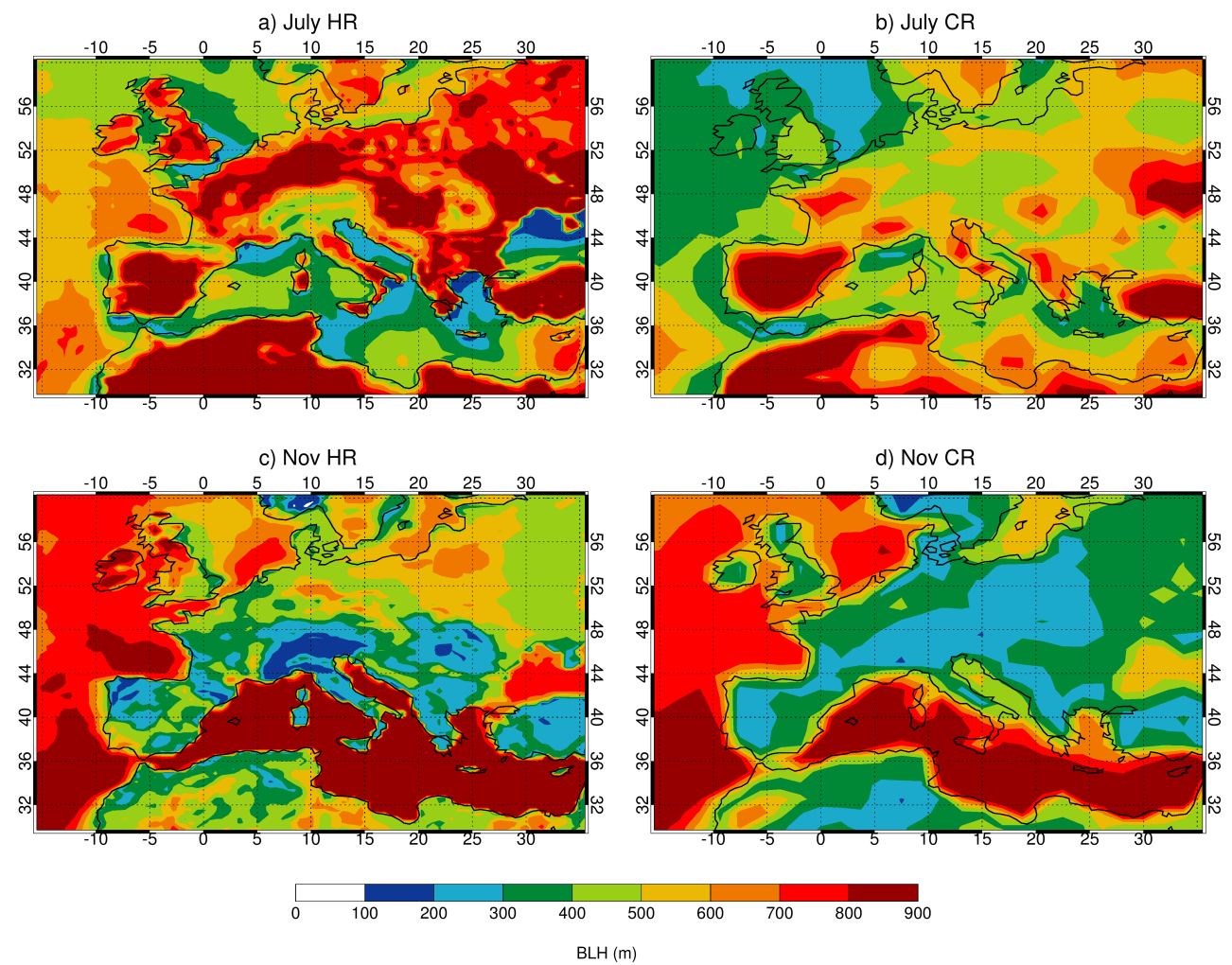

Fig. 7. Monthly mean boundary layer height.

observed differences in the modelled surface ozone in July are less affected by chemical differences and can be partly attributed to differences in the representation of the BLH in the two model configurations.

At the regional scale, the HR configuration generally gives a better agreement with observations from the EMEP network, with better correlation coefficients and smaller MBE, particularly for November, when the CR configuration has a tendency to largely overestimate the very low ozone concentrations associated with more polluted sites. The chemical regime analysis shows that, for the month of November, the CR configuration misses the very VOC-limited regimes which are generally associated with ozone titration by NO and therefore low ozone concentrations. The OPE analysis also shows that model differences at the regional scale are largest in November, with CR overestimating the average OPE over a small European domain by $\sim 21 \%$, while being only $\sim 1 \%$ higher in July. For November, emission resolution accounts for $\sim 30 \%$ of the observed differences between $\mathrm{CR}$ and HR average European surface ozone concentrations. In July, increased ozone photochemical production leads to generally higher ozone concentrations across Europe. Differences between the two model configurations are smaller and both have a tendency to overestimate ozone values compared to observations, as indicated by the larger MBE values. The chemical regime and OPE analyses show that in the summer the influence of resolution on modelled chemistry is small. Analysis of BLH for the two model configurations suggests that in the summer month of July, when photochemical production and ozone concentrations are higher, vertical mixing plays a key role in determining surface ozone concentrations and changes in BLH due to model resolution are largely responsible for the observed differences between HR and CR.

The model's ability to represent high and low ozone extremes in megacities was shown to be very sensitive to horizontal resolution. The high resolution model generally gives better results compared to observations and is better able to capture the high probability of very low surface ozone in very polluted urban areas. The HR configuration also gives a better representation of surface characteristics and regional transitions in chemical regimes from $\mathrm{VOC}$ to $\mathrm{NO}_{\mathrm{x}}$-limited environments. This could have implications for modelling in support of regional policies, as lowering $\mathrm{NO}_{\mathrm{x}}$ in a VOC-limited environment can lead to increased ozone production.

\section{Supplementary material related to this article is available online at http://www.atmos-chem-phys.net/14/ 3899/2014/acp-14-3899-2014-supplement.pdf.}


Acknowledgements. The research leading to these results has received funding from the European Union's Seventh Framework Programme FP/2007-2011 within the project MEGAPOLI, under grant agreement no. 212520. Z. S. Stock wishes to thank the Natural Environment Research Council for studentship funding. We acknowledge N. L. Abraham, P. J. Telford and A. T. Archibald for the long-term support of UKCA.

Edited by: J. Ma

\section{References}

Archibald, A., Levine, J., Abraham, N., Cooke, M., Edwards, P., Heard, D., Jenkin, M., Karunaharan, A., Pike, R., Monks, P., Shallcross, D., Telford, P., Whalley, L., and Pyle, J.: Impacts of $\mathrm{HO}_{\mathrm{x}}$ regeneration and recycling in the oxidation of isoprene: Consequences for the composition of past, present and future atmospheres, Geophys. Res. Lett., 38, L05804, doi:10.1029/2010GL046520, 2011.

Baklanov, A., Lawrence, M., Pandis, S., Mahura, A., Finardi, S., Moussiopoulos, N., Beekmann, M., Laj, P., Gomes, L., Jaffrezo, J.-L., Borbon, A., Coll, I., Gros, V., Sciare, J., Kukkonen, J., Galmarini, S., Giorgi, F., Grimmond, S., Esau, I., Stohl, A., Denby, B., Wagner, T., Butler, T., Baltensperger, U., Builtjes, P., van den Hout, D., van der Gon, H. D., Collins, B., Schluenzen, H., Kulmala, M., Zilitinkevich, S., Sokhi, R., Friedrich, R., Theloke, J., Kummer, U., Jalkinen, L., Halenka, T., Wiedensholer, A., Pyle, J., and Rossow, W. B.: MEGAPOLI: concept of multi-scale modelling of megacity impact on air quality and climate, Adv. Sci. Res., 4, 115-120, 2010.

Borrego, C., Monteiro, A., Ferreira, J., Miranda, A., Costa, A., Carvalho, A., and Lopes, M.: Procedures for estimation of modelling uncertainty in air quality assessment, Environ. Int., 34, 613-620, 2008.

Butler, T. M. and Lawrence, M. G.: The influence of megacities on global atmospheric chemistry: a modelling study, Environ. Chem., 6, 219-225, 2009.

Butler, T. M., Stock, Z. S., Russo, M. R., Denier van der Gon, H. A. C., and Lawrence, M. G.: Megacity ozone air quality under four alternative future scenarios, Atmos. Chem. Phys., 12, 44134428, doi:10.5194/acp-12-4413-2012, 2012.

Cariolle, D., Caro, D., Paoli, R., Hauglustaine, D. A., Cuénot, B., Cozic, A., and Paugam, R.: Parameterization of plume chemistry into large-scale atmospheric models: Application to aircraft $\mathrm{NO}_{\mathrm{x}}$ emissions, J. Geophys. Res.-Atmos., 114, D19302, doi:10.1029/2009JD011873, 2009.

Chameides, W. and Walker, J.: A photochemical theory for tropospheric ozone, J. Geophys. Res., 78, 8751-8760, doi:10.1029/JC078i036p08751, 1973.

Charlton-Perez, C. L., Evans, M. J., Marsham, J. H., and Esler, J. G.: The impact of resolution on ship plume simulations with $\mathrm{NO}_{\mathrm{x}}$ chemistry, Atmos. Chem. Phys., 9, 7505-7518, doi:10.5194/acp9-7505-2009, 2009.

Coleman, L., Varghese, S., Tripathi, O., Jennings, S., and O'Dowd, C.: Regional-scale ozone deposition to NorthEast Atlantic waters, Advances in Meteorology, 243701, doi:10.1155/2010/243701, 2010.

Dall'Amico, M., Gray, L. J., Rosenlof, K. H., Scaife, A. A., Shine, K. P., and Stott, P. A.: Stratospheric temperature trends: impact of ozone variability and the QBO, Clim. Dynam., 34, 381-398, 2010.

EMEP, 2007: Ozone measurements 2005, Tech. rep., EMEP/CCCReport 2/2007, edited by: Fjæraa, A. M. and Hjellbrekke, A. G., http://www.nilu.no/projects/ccc/reports/cccr2-2007.pdf (last access: July 2013), 2007.

Esler, J. G., Roelofs, G. J., Köhler, M. O., and O’Connor, F. M.: A quantitative analysis of grid-related systematic errors in oxidising capacity and ozone production rates in chemistry transport models, Atmos. Chem. Phys., 4, 1781-1795, doi:10.5194/acp-41781-2004, 2004.

Fiore, A., Dentener, F., Wild, O., Cuvelier, C., Schultz, M., Hess, P., Textor, C., Schulz, M., Doherty, R., Horowitz, L., MacKenzie, I., Sanderson, M., Shindell, D., Stevenson, D., Szopa, S., Van Dingenen, R., Zeng, G., Atherton, C., Bergmann, D., Bey, I., Carmichael, G., Collins, W., Duncan, B., Faluvegi, G., Folberth, G., Gauss, M., Gong, S., Hauglustaine, D., Holloway, T., Isaksen, I., Jacob, D., Jonson, J., Kaminski, J., Keating, T., Lupu, A., Marmer, E., Montanaro, V., Park, R., Pitari, G., Pringle, K., Pyle, J., Schroeder, S., Vivanco, M., Wind, P., Wojcik, G., Wu, S., and Zuber, A.: Multimodel estimates of intercontinental source-receptor relationships for ozone pollution, J. Geophys. Res.-Atmos., 114, D04301, doi:10.1029/2008JD010816, 2009.

Franke, K., Eyring, V., Sander, R., Hendricks, J., Lauer, A., and Sausen, R.: Toward effective emissions of ships in global models, Meteorol. Z., 17, 117-129, doi:10.1127/0941-2948/2008/0277, 2008.

Granier, C., Guenther, A., Lamarque, J., Mieville, A., Muller, J., Olivier, J., Orlando, J., Peters, J., Petron, G., Tyndall, G., and Wallens, S.: POET, a database of surface emissions of ozone precursors, available at: http://www.pole-ether.fr/eccad (last access: May 2013), ECCAD-Ether Database, 2005.

Gregory, D. and Rowntree, P.: A mass flux convection scheme with representation of cloud ensemble characteristics and stabilitydependent closure, Mon. Weather Rev., 118, 1483-1506, 1990.

Gurjar, B. R., Butler, T. M., Lawrence, M. G., and Lelieveld, J.: Evaluation of emissions and air quality in megacities, Atmos. Environ., 42, 1593-1606, 2008.

Hewitt, H. T., Copsey, D., Culverwell, I. D., Harris, C. M., Hill, R. S. R., Keen, A. B., McLaren, A. J., and Hunke, E. C.: Design and implementation of the infrastructure of HadGEM3: the nextgeneration Met Office climate modelling system, Geosci. Model Dev., 4, 223-253, doi:10.5194/gmd-4-223-2011, 2011.

Hodnebrog, Ø., Stordal, F., and Berntsen, T.: Does the resolution of megacity emissions impact large scale ozone?, Atmos. Environ., 45, 6852-6862, doi:10.1016/j.atmosenv.2011.01.012, 2011.

HTAP: Hemispheric Transport of Air Pollution 2010, Part A: ozone and particulate matter, air pollution studies No.17, Tech. rep., United Nations, New York and Geneva, edited by: Dentener F., Keating T., and Akimoto H., 2010.

Jacob, D. J. and Winner, D. A.: Effect of climate change on air quality, Atmos. Environ., 43, 51-63, doi:10.1016/j.atmosenv.2008.09.051, 2009.

Jacob, D. J., Logan, J. A., Gardner, G. M., Yevich, R. M., Spivakovsky, C. M., Wofsy, S. C., Sillman, S., and Prather, M. J.: Factors regulating ozone over the United States and its export to the global atmosphere, J. Geophys. Res.-Atmos., 98, 1481714826, doi:10.1029/98JD01224, 1993. 
Jang, J. C. C., Jeffries, H. E., Byun, D., and Pleim, J. E.: Sensitivity of ozone to model grid resolution .1. Application of highresolution regional acid deposition model, Atmos. Environ., 29, 3085-3100, doi:10.1016/1352-2310(95)00118-I, 1995.

Jenkin, M. and Clemitshaw, K.: Ozone and other secondary photochemical pollutants: chemical processes governing their formation in the planetary boundary layer, Atmos. Environ., 34, 24992527, 2000.

Koumoutsaris, S. and Bey, I.: Can a global model reproduce observed trends in summertime surface ozone levels?, Atmos. Chem. Phys., 12, 6983-6998, doi:10.5194/acp-12-6983-2012, 2012.

Lamarque, J.-F., Bond, T. C., Eyring, V., Granier, C., Heil, A., Klimont, Z., Lee, D., Liousse, C., Mieville, A., Owen, B., Schultz, M. G., Shindell, D., Smith, S. J., Stehfest, E., Van Aardenne, J., Cooper, O. R., Kainuma, M., Mahowald, N., McConnell, J. R., Naik, V., Riahi, K., and van Vuuren, D. P.: Historical (1850-2000) gridded anthropogenic and biomass burning emissions of reactive gases and aerosols: methodology and application, Atmos. Chem. Phys., 10, 7017-7039, doi:10.5194/acp10-7017-2010, 2010.

Law, K. and Pyle, J.: Modeling trace gas budgets in the troposphere .1. Ozone and odd nitrogen, J. Geophys. Res.-Atmos., 98, 18377-18400, 1993a.

Law, K. and Pyle, J.: Modeling trace gas budgets in the troposphere .2. $\mathrm{CH}_{4}$ and CO, J. Geophys. Res.-Atmos., 98, 18401-18412, $1993 b$.

Law, K. S., Plantevin, P. H., Shallcross, D. E., Rogers, H. L., Pyle, J. A., Grouhel, C., Thouret, V., and Marenco, A.: Evaluation of modeled $\mathrm{O}_{3}$ using measurement of ozone by Airbus in-service aircraft (MOZAIC) data, J. Geophys. Res.-Atmos., 103, 2572125737, doi:10.1029/98JD01482, 1998.

Lawrence, M. G., Butler, T. M., Steinkamp, J., Gurjar, B. R., and Lelieveld, J.: Regional pollution potentials of megacities and other major population centers, Atmos. Chem. Phys., 7, 39693987, doi:10.5194/acp-7-3969-2007, 2007.

Liang, J. and Jacobson, M. Z.: Effects of subgrid segregation on ozone production efficiency in a chemical model, Atmos. Environ., 34, 2975-2982, 2000.

Lin, X., Trainer, M., and Liu, S. C.: On the nonlinearity of the tropospheric ozone production, J. Geophys. Res.-Atmos., 93, 1587915888, doi:10.1029/JD093iD12p15879, 1988.

Liu, S. C., Trainer, M., Fehsenfeld, F. C., Parrish, D. D., Williams, E. J., Fahey, D. W., Hübler, G., and Murphy, P. C.: Ozone production in the rural troposphere and the implications for regional and global ozone distributions, J. Geophys. Res.-Atmos., 92, 41914207, doi:10.1029/JD092iD04p04191, 1987.

Lock, A. P., Brown, A. R., Bush, M. R., Martin, G. M., and Smith, R. N. B.: Boundary layer mixing scheme. Part I: scheme description and single-column model tests, Mon. Weather Rev., 128, 3187-3199, 2000.

Martins, H.: Urban compaction or dispersion? An air quality modelling study, Atmos. Environ., 54, 60-72, doi:10.1016/j.atmosenv.2012.02.075, 2012.

Meijer, E. W., van Velthoven, P. F. K., Wauben, W. M. F., Beck, J. P., and Velders, G. J. M.: The effects of the conversion of nitrogen oxides in aircraft exhaust plumes in global models, Geophys. Res. Lett., 24, 3013-3016, doi:10.1029/97GL53156, 1997.
Molina, M. J. and Molina, L. T.: Megacities and atmospheric pollution, JAPCA J. Air Waste Ma., 54, 644-680, 2004.

Monks, P. S., Granier, C., Fuzzi, S., Stohl, A., Williams, M. L., Akimoto, H., Amann, M., Baklanov, A., Baltensperger, U., Bey, I., Blake, N., Blake, R. S., Carslaw, K., Cooper, O. R., Dentener, F., Fowler, D., Fragkou, E., Frost, G. J., Generoso, S., Ginoux, P., Grewe, V., Guenther, A., Hansson, H. C., Henne, S., Hjorth, J., Hofzumahaus, A., Huntrieser, H., Isaksen, I. S. A., Jenkin, M. E., Kaiser, J., Kanakidou, M., Klimont, Z., Kulmala, M., Laj, P., Lawrence, M. G., Lee, J. D., Liousse, C., Maione, M., McFiggans, G., Metzger, A., Mieville, A., Moussiopoulos, N., Orlando, J. J., O’Dowd, C. D., Palmer, P. I., Parrish, D. D., Petzold, A., Platt, U., Pöschl, U., Prevot, A. S. H., Reeves, C. E., Reimann, S., Rudich, Y., Sellegri, K., Steinbrecher, R., Simpson, D., ten Brink, H., Theloke, J., van der Werf, G. R., Vautard, R., Vestreng, V., Vlachokostas, C., and von Glasow, R.: Atmospheric composition change - global and regional air quality, Atmos. Environ., 43, 5268-5350, doi:10.1016/j.atmosenv.2009.08.021, 2009.

Neu, J. L., Prather, M. J., and Penner, J. E.: Global atmospheric chemistry: Integrating over fractional cloud cover, J. Geophys. Res.-Atmos., 112, D11306, doi:10.1029/2006JD008007, 2007.

O'Connor, F. M., Johnson, C. E., Morgenstern, O., Abraham, N. L., Braesicke, P., Dalvi, M., Folberth, G. A., Sanderson, M. G., Telford, P. J., Voulgarakis, A., Young, P. J., Zeng, G., Collins, W. J., and Pyle, J. A.: Evaluation of the new UKCA climatecomposition model - Part 2: The Troposphere, Geosci. Model Dev., 7, 41-91, doi:10.5194/gmd-7-41-2014, 2014.

Olivier, J., Peters, J., Granier, C., Petron, G., Muller, J., and Wallens, S.: Present and future surface emissions of atmospheric compounds, pOET Report 2, EU project EVK2-1999-00011, 2003.

Parrish, D., Singh, H., Molina, L., and Madronich, S.: Air quality progress in North American megacities: A review, Atmos. Environ., 45, 7015-7025, 2011.

Parrish, D. D., Law, K. S., Staehelin, J., Derwent, R., Cooper, O. R., Tanimoto, H., Volz-Thomas, A., Gilge, S., Scheel, H.-E., Steinbacher, M., and Chan, E.: Long-term changes in lower tropospheric baseline ozone concentrations at northern mid-latitudes, Atmos. Chem. Phys., 12, 11485-11504, doi:10.5194/acp-1211485-2012, 2012.

Pöschl, U., von Kuhlmann, R., Poisson, N., and Crutzen, P.: Development and intercomparison of condensed isoprene oxidation mechanisms for global atmospheric modeling, J. Atmos. Chem., 37, 29-52, 2000.

Price, C. and Rind, D.: A simple lightning parameterization for calculating global lightning distributions, J. Geophys. Res.-Atmos., 97, 9919-9933, doi:10.1029/92JD00719, 1992.

Pyle, J. and Zavody, A.: The modeling problems associated with spatial averaging, Q. J. Roy. Meteor. Soc., 116, 753-766, 1990.

Riahi, K., Rao, S., Krey, V., Cho, C., Chirkov, V., Fischer, G., Kindermann, G., Nakicenovic, N., and Rafaj, P.: RCP 8.5 - A scenario of comparatively high greenhouse gas emissions, Climatic Change, 109, 33-57, doi:10.1007/s10584-011-0149-y, 2011.

Russo, M. R., Marécal, V., Hoyle, C. R., Arteta, J., Chemel, C., Chipperfield, M. P., Dessens, O., Feng, W., Hosking, J. S., Telford, P. J., Wild, O., Yang, X., and Pyle, J. A.: Representation of tropical deep convection in atmospheric models - Part 1: Meteorology and comparison with satellite observations, Atmos. Chem. Phys., 11, 2765-2786, doi:10.5194/acp-11-27652011, 2011. 
Sillman, S.: The use of $\mathrm{NO}_{\mathrm{y}}, \mathrm{H}_{2} \mathrm{O}_{2}$, and $\mathrm{HNO}_{3}$ as indicators for ozone- $\mathrm{NO}_{\mathrm{x}}$-hydrocarbon sensitivity in urban locations, J. Geophys. Res.-Atmos., 100, 14175-14188, doi:10.1029/94JD02953, 1995.

Sillman, S.: The relation between ozone, $\mathrm{NO}_{\mathrm{x}}$ and hydrocarbons in urban and polluted rural environments, Atmos. Environ., 33, 1821-1845, 1999.

Sillman, S., Logan, J., and Wofsy, S.: A regional scale-model for ozone in the United-States with subgrid representation of urban and power-plant plumes, J. Geophys. Res.-Atmos., 95, 57315748, doi:10.1029/JD095iD05p05731, 1990.

Simmons, A. J., Uppala, S., Dee, D., and Kobayashi, S.: ERAInterim: New ECMWF reanalysis products from 1989 onwards, ECMWF Newsletter, No. 110, 25-35, ECMWF, Reading, UK, 2007.

Stevenson, D. S., Dentener, F. J., Schultz, M. G., Ellingsen, K., van Noije, T. P. C., Wild, O., Zeng, G., Amann, M., Atherton, C. S., Bell, N., Bergmann, D. J., Bey, I., Butler, T., Cofala, J., Collins, W. J., Derwent, R. G., Doherty, R. M., Drevet, J., Eskes, H. J., Fiore, A. M., Gauss, M., Hauglustaine, D. A., Horowitz, L. W., Isaksen, I. S. A., Krol, M. C., Lamarque, J. F., Lawrence, M. G., Montanaro, V., Muller, J. F., Pitari, G., Prather, M. J., Pyle, J. A., Rast, S., Rodriguez, J. M., Sanderson, M. G., Savage, N. H., Shindell, D. T., Strahan, S. E., Sudo, K., and Szopa, S.: Multimodel ensemble simulations of present-day and near-future tropospheric ozone, J. Geophys. Res.-Atmos., 111, D08301, doi:10.1029/2005JD006338, 2006.

Stock, Z. S., Russo, M. R., Butler, T. M., Archibald, A. T., Lawrence, M. G., Telford, P. J., Abraham, N. L., and Pyle, J. A.: Modelling the impact of megacities on local, regional and global tropospheric ozone and the deposition of nitrogen species, Atmos. Chem. Phys., 13, 12215-12231, doi:10.5194/acp-1312215-2013, 2013.

Tang, Y.: A case study of nesting simulation for the Southern Oxidants Study 1999 at Nashville, Atmos. Environ., 36, 1691-1705, 2002.

Telford, P. J., Braesicke, P., Morgenstern, O., and Pyle, J. A.: Technical Note: Description and assessment of a nudged version of the new dynamics Unified Model, Atmos. Chem. Phys., 8, 17011712, doi:10.5194/acp-8-1701-2008, 2008.

Telford, P. J., Lathière, J., Abraham, N. L., Archibald, A. T., Braesicke, P., Johnson, C. E., Morgenstern, O., O'Connor, F. M., Pike, R. C., Wild, O., Young, P. J., Beerling, D. J., Hewitt, C. N., and Pyle, J.: Effects of climate-induced changes in isoprene emissions after the eruption of Mount Pinatubo, Atmos. Chem. Phys., 10, 7117-7125, doi:10.5194/acp-10-7117-2010, 2010.

Telford, P. J., Abraham, N. L., Archibald, A. T., Braesicke, P., Dalvi, M., Morgenstern, O., O'Connor, F. M., Richards, N. A. D., and Pyle, J. A.: Implementation of the Fast-JX Photolysis scheme (v6.4) into the UKCA component of the MetUM chemistry-climate model (v7.3), Geosci. Model Dev., 6, 161177, doi:10.5194/gmd-6-161-2013, 2013.
Thuburn, J. and Tan, D.: A parameterization of mixdown time for atmospheric chemicals, J. Geophys. Res., 102, 13037-13049, doi:10.1029/97JD00408, 1997.

Tie, X., Brasseur, G., and Ying, Z.: Impact of model resolution on chemical ozone formation in Mexico City: application of the WRF-Chem model, Atmos. Chem. Phys., 10, 8983-8995, doi:10.5194/acp-10-8983-2010, 2010.

van der Werf, G. R., Randerson, J. T., Giglio, L., Collatz, G. J., Mu, M., Kasibhatla, P. S., Morton, D. C., DeFries, R. S., Jin, Y., and van Leeuwen, T. T.: Global fire emissions and the contribution of deforestation, savanna, forest, agricultural, and peat fires (19972009), Atmos. Chem. Phys., 10, 11707-11735, doi:10.5194/acp10-11707-2010, 2010.

Vingarzan, R.: A review of surface ozone background levels and trends, Atmos. Environ., 38, 3431-3442, doi:10.1016/j.atmosenv.2004.03.030, 2004.

Walters, D. N., Best, M. J., Bushell, A. C., Copsey, D., Edwards, J. M., Falloon, P. D., Harris, C. M., Lock, A. P., Manners, J. C., Morcrette, C. J., Roberts, M. J., Stratton, R. A., Webster, S., Wilkinson, J. M., Willett, M. R., Boutle, I. A., Earnshaw, P. D., Hill, P. G., MacLachlan, C., Martin, G. M., Moufouma-Okia, W., Palmer, M. D., Petch, J. C., Rooney, G. G., Scaife, A. A., and Williams, K. D.: The Met Office Unified Model Global Atmosphere 3.0/3.1 and JULES Global Land 3.0/3.1 configurations, Geosci. Model Dev., 4, 919-941, doi:10.5194/gmd-4-919-2011, 2011.

West, J. J., Naik, V., Horowitz, L. W., and Fiore, A. M.: Effect of regional precursor emission controls on long-range ozone transport - Part 1: Short-term changes in ozone air quality, Atmos. Chem. Phys., 9, 6077-6093, doi:10.5194/acp-9-6077-2009, 2009.

Wild, O. and Akimoto, H.: Intercontinental transport of ozone and its precursors in a three-dimensional global CTM, J. Geophys. Res.-Atmos., 106, 27729-27744, 2001.

Wild, O. and Prather, M.: Global tropospheric ozone modeling: Quantifying errors due to grid resolution, J. Geophys. Res.Atmos., 111, doi:10.1029/2005JD006605, 2006.

Yoshitomi, M., Wild, O., and Akimoto, H.: Contributions of regional and intercontinental transport to surface ozone in the Tokyo area, Atmos. Chem. Phys., 11, 7583-7599, doi:10.5194/acp-11-7583-2011, 2011.

Zeng, G. and Pyle, J.: Changes in tropospheric ozone between 2000 and 2100 modeled in a chemistry-climate model, Geophys. Res. Lett., 30, 1392, doi:10.1029/2002GL016708, 2003. 